\title{
PRINCIPAL COMPONENT ANALYSIS (PCA) UNTUK MENGATASI MULTIKOLINIERITAS TERHADAP FAKTOR ANGKA KEJADIAN PNEUMONIA BALITA DI JAWA TIMUR TAHUN 2014
}

\author{
Fita Mega Kusuma, Arief Wibowo \\ Fakultas Kesehatan Masyarakat, Universitas Airlangga ${ }^{1}$ \\ Fakultas Kesehatan Masyarakat, Universitas Airlangga ${ }^{2}$ \\ Alamat korespondensi: Fita Mega Kusuma \\ E-mail: fita.mega@ymail.com
}

\begin{abstract}
Correlation between independent variables in multiple linear regression model called multicollinearity. One of the assumptions of multiple linear regression free from multicollinearity problem. Principal Component Analysis (PCA) method in this study aims to overcome the existence of multicollinearity in multiple linear regression and know the dominant factor to the research. PCA method has the advantage of clearing the correlation without losing the original variable. Case study a risk factor that affects the incidence of pneumonia infants in East Java 2014. This non reactive research because uses publication data of health profil of East Java. Result of this research multicollinearity problem in research data when detected by VIF/tolerance method. Variable of vitamin A coverage, measles immunization coverage and health service coverage are the variables that observed multicollinearity. A multicollinearity solution produces (FI) or new variable (coverage of vitamin A, immunization measles and health service), reduction of three variables that multicollinearity to not multicollinearity with VIF value of $1.608<10$. Results of this study also proves the weakness of PCA method in analyzing the significance. PCA method shows the most influencing factors on the incidence of pneumonia of children under five year. Dominant factor in this research coverage of infant health services covering, coverage of vitamin $A$ and coverage of measles immunization. Coverage factor of health services has a coefficient matrix value of 0.890 or $89 \%$ more influential than other factor.
\end{abstract}

Keywords: PCA (Principal Component Analysis), VIF/Tolerance, multicollinearity, pneumonia children under five year

\begin{abstract}
ABSTRAK
Adanya korelasi antar variabel bebas di dalam model regresi linier berganda disebut multikolinieritas. Salah satu asumsi yang harus terpenuhi adalah tidak adanya multikolinieritas. Asumsi klasik untuk memenuhi syarat analisis regresi linier berganda. Penerapan metode PCA (Principal Component Analysis) pada penelitian ini bertujuan untuk mengatasi adanya multikolinieritas pada regresi linier berganda serta mengetahui faktor yang dominan terhadap penelitian. Kelebihan dari metode PCA yaitu dapat membersihkan korelasi tanpa menghilangkan variabel aslinya. Penelitian ini menggunakan studi kasus tentang faktor risiko yang memengaruhi angka kejadian pneumonia balita di Jawa Timur tahun 2014. Jenis penelitian ini merupakan unobtrusif method karena menggunakan data publikasi Profil Kesehatan Jawa Timur. Hasil penelitian ini menunjukkan adanya masalah multikolinieritas pada data penelitian ketika di deteksi dengan metode VIF/tolerance. Variabel cakupan pemberian vitamin A, cakupan imunisasi campak dan cakupan pelayanan kesehatan balita minimal $8 \mathrm{x}$ merupakan variabel yang mengalami mutikolinieritas. Penyelesaian multikolinieritas menghasilkan satu variabel bebas baru (F1). Variabel baru (F1) merupakan reduksi dari tiga variabel yang bermultikol menjadi tidak bermultikol dengan nilai VIF sebesar 1,608 $<10$. Hasil dari penelitian ini melalui analisis re-transformasi regresi yang membuktikan kelemahan dari metode PCA. Kelemahan terjadi dalam menganalisis signifikansi hubungan variabel bebas terhadap variabel terikat. Metode PCA juga menunjukkan faktor dominan yang memengaruhi angka kejadian pneumonia balita yaitu faktor cakupan pelayanan kesehatan balita yang meliputi cakupan pemberian vitamin A dan cakupan imunisasi campak. Faktor cakupan pelayanan kesehatan balita memiliki nilai koefisien matrix sebesar 0,890 atau 89\% lebih berpengaruh pada kejadian pneumonia balita daripada faktor lainya.
\end{abstract}

Kata kunci: PCA (Principal Component Analysis), VIF/Tolerance, multikolinieritas, Pneumonia Balita 


\section{PENDAHULUAN}

Masalah multikolinieritas pada regresilinier berganda adalah adanya korelasi yang tinggi diantara variabel bebasnya. Asumsi klasik tidak adanya multikolinieritas dalam suatu model regresi linier berganda harus terpenuhi, karena dengan adanya multikolinieritas dalam suatu model regresi dapat mengakibatkan hubungan antara variabel terikat dan variabel bebas terganggu. Variabel yang seharusnya menyatakan signifikan menjadi sebaliknya. Penyebab terjadinya kasus multikolinearitas pada suatu model regresi adalah masalah teoritis dalam pembentukan model regresi yang dipergunakan atau menggunakan variabel bebas yang hampir dan bahkan sama. Hal ini juga dapat terjadi jika terlalu kecil jumlah pengamatan yang akan dianalisa dengan model regresi.

Penggunaan Metode Principal Component Analysis (PCA) pada penelitian ini bertujuan untuk mengatasi masalah multikolinieritas. Metode PCA digunakan karena cukup efektif, dapat mengatasi multikolinearitas di berbagai kondisi dan menghilangkan korelasi diantara variabel bebas hingga tidak berkorelasi sama sekali. Kelebihan metode PCA, salah satunya adalah dapat menghilangkan korelasi tanpa harus mengurangi atau menghilangkan jumlah variabel aslinya, sehingga masalah multikolinearitas akan dapat teratasi. Hasil dari metode PCA juga dapat menganalisis faktor yang dominan atau yang lebih berpengaruh terhadap angka kejadian pneumonia pada balita di Jawa Timur.

Analisis ini menggunakan data sekunder angka kejadian pneumonia balita di Jawa Timur tahun 2014. Salah satu penyakit yang menyebabkan morbiditas dan mortalitas di seluruh dunia adalah pneumonia, dimana sekitar lima juta anak balita menghadapi kematian sebagai konsekuensi dari pneumonia. Berdasarkan data UNICEF pada tahun 2012, sebanyak 21 ribu bayi dan balita di Indonesia meninggal karena pneumonia atau $14 \%$ kematian bayi dan balita disebabkan oleh pneumonia. Kejadian kematian pada balita usia 2 bulan disebabkan oleh penyakit diare, pneumonia, campak, malaria dan malnutrisi yang kurang lebih mencapai $70 \%$. Sekitar 40-60\% setiap tahunnya telah ditemukan penyakit ISPA pada balita sebagai faktor risiko terjadinya pneumonia balita. Faktor risiko yang cenderung meningkatkan kejadian pneumonia antara lain umur, jenis kelamin, status gizi, imunisasi campak, vitamin A, ASI eksklusif, PHBS dan rumah sehat. (Kementerian Kesehatan RI tahun 2004).

Kasus pneumonia hingga saat ini masih menjadi salah satu penyebab tertinggi kematian balita di Jawa Timur. Gambaran cakupan penemuan kasus pneumonia balita pada data Profil Kesehatan Jawa Timur tercatat tahun 2014 mencapai 110975 atau 35,07\%. Dari 38 kabupaten/ kota di Provinsi Jawa Timur hanya 1 (satu) kabupaten yang memenuhi target cakupan penemuan penderita pneumonia balita sebesar $100 \%$, sesuai dengan pendataan jumlah kasus. Satu kabupaten tersebut yaitu Kabupaten Gresik. Beberapa kabupaten/kota yang sudah mendekati capaian target penemuan kasus $>60 \%$ adalah Kabupaten Bojonegoro, Kota Madiun, Kota Mojokerto, Kabupaten Mojokerto, Kabupaten Tuban, Kota Pasuruan dan Kabupaten Bangkalan, sedangkan kabupaten/kota lainnya masih belum bahkan masih jauh dari target nasional. Hal ini yang mendasari penelitian ini mengambil data kasus pneumonia balita di Jawa Timur tahun 2014 dengan tujuan untuk mengetahui faktor apa yang paling memengaruhinya. Tujuan dari penelitian ini adalah mengetahui faktor risiko dominan yang memengaruhi angka kejadian pneumonia balita di Jawa Timur tahun 2014. Berdasarkan latar belakang dan tujuan yang telah dipaparkan, manfaat dari penelitian ini adalah memberikan informasi mengenai faktor risiko dominan yang memengaruhi angka kejadian pneumonia balita di Jawa Timur. Hal ini diharapkan dapat bermanfaat bagi instansi yang terkait sehingga dapat dijadikan pertimbangan untuk membuat kebijakan kesehatan khususnya masalah pneumonia pada balita.

\section{METODE PENELITIAN}

Jenis penelitian ini adalah penelitian observasional, dimana data yang digunakan ialah data sekunder. Analis data sekunder untuk dilakukan pengamatan terhadap data-data yang sudah tersedia. Ditinjau dari segi waktu penelitian ini merupakan penelitian cross sectional, karena hanya dilakukan dalam satu waktu pada tahun 
yang sama. Penelitian ini merupakan penelitian non reaktif (non reactive research) disebut juga pengukuran unobtrusive method.

Unit analisis yang digunakan pada penelitian ini adalah Kabupaten/Kota di Provinsi Jawa Timur tahun 2014, dengan jumlah 38 kabupaten/ kota. Data yang digunakan pada penelitian ini adalah data publikasi profil kesehatan Jawa Timur tahun 2014. Pengumpulan data laporan profil kesehatan Jawa Timur terdiri dari data laporan program kesehatan per Kabupaten/Kota. Laporan program kesehatan Kabupaten/Kota terdiri dari puskesmas per Kecamatannya.

Variabel pada penelitian ini meliputi satu variabel terikat (dependen) dan tujuh variabel bebas (independen). Variabel dependen adalah jumlah penderita pneumonia balita yang ditemukan dan ditangani $(Y)$, sedangkan variabel independennya meliputi cakupan pemberian ASI eksklusif (X1), cakupan balita gizi buruk (X2), cakupan pemberian vitamin A (X3), cakupan status imunisasi campak (X4), cakupan pelayanan kesehatan balita (X5), cakupan rumah tangga yang berperilaku hidup bersih dan sehat (X6) dan cakupan rumah sehat (X7).

Data pada penelitian ini merupakan data sekunder. Data didapatkan dari laporan data Profil Dinas Kesehatan Provinsi Jawa Timur tahun 2014. Data sekunder ini adalah angka jumlah kejadian pneumonia pada balita di Provinsi Jawa Timur tahun 2014.

Teknik analisis data pada penelitian ini diolah dengan uji statistik regresi linier berganda. Hal ini karena skala data pada penelitian adalah rasio dengan tujuan menganalisis faktor risiko yang dominan terhadap angka kejadian pneumonia di Jawa Timur tahun 2014. Masalah multikolinieritas data pada penelitian ini akan diolah secara statistik menggunakan metode VIF/ Tolerance untuk mendeteksi multikolinearitas dalam suatu model regresi pada data faktor risiko pneumonia pada balita di Provinsi Jawa Timur tahun 2014. Berdasarkan hal tersebut untuk mengatasi multikolinearitas, penelitian ini menggunakan metode PCA. Analisis data dan interpretasi hasil dilakukan dengan meregresikan kembali hasil dari PCA ke regresi linier berganda. Hal ini dilakukan untuk memastikan bahwa metode PCA dapat mengatasi masalah multikolinieritas dan menginterpretasikan hasil faktor yang dominan dari penelitian.

PCA sesuai prosedurnya melakukan analisis dengan cara mereduksi variabel yang memiliki masalah multikolinieritas menjadi satu variabel baru. Satu variabel baru tersebut adalah variabel yang dapat mewakili variabel-variabel lain yang bermultikolinieritas di analisis regresi sebelumnya.

Hasil interpretasi akhir dari penelitian dilakukan dengan meregresikan kembali variabel baru ke regresi linier berganda. Hal ini bertujuan untuk melihat hubungan yang signifikan dari variabel bebas terhadap variabel dependennya. Faktor yang dominan atau yang paling berpengaruh terhadap variabel dependen juga akan dapat diketahui dari hasil analisis metode PCA.

\section{HASIL PENELITIAN}

Berdasarkan laporan Profil Kesehatan Provinsi Jawa Timur, cakupan penemuan kasus pneumonia pada balita pada tahun 2014 mencapai presentase diatas $30 \%$.

Tabel 1. Hasil Angka Kejadian Temuan Kasus Pneumonia Balita di Jawa Timur

\begin{tabular}{ccc}
\hline Tahun & $\begin{array}{c}\text { Jumlah Kejadian } \\
\text { Pneumonia Balita di } \\
\text { Jawa Timur }\end{array}$ & Persentase \\
\hline 2012 & 84392 & $27,08 \%$ \\
2013 & 57154 & $24,46 \%$ \\
2014 & 110975 & $35,07 \%$ \\
\hline
\end{tabular}

Sumber: Profil Kesehatan Provinsi Jawa Timur tahun 2012-2014

Tabel 1 menunjukkan tahun 2014 memiliki prosentase $35,07 \%$, sedangkan tahun 2015 tidak dicantumkan. Hasil pelaporan data dari profil kesehatan Jawa Timur tahun 2015 mengalami kenaikan persentase $76,8 \%$ dengan jumlah kejadian 99.190 balita pneumonia. Hasil pada tahun 2016 juga tidak dicantumkan karena data publikasi profil kesehatan Jawa Timur tahun tersebut belum dipublikasikan. Kenaikan penemuan kasus pneumonia balita hampir dua kali lipat dari tahun 2013 ke 2014, hal tersebut 
perlu mendapatkan perhatian baik dari pelaksana program, penentu kebijakan dan masyarakat.

Hasil analisis data menggunakan uji statistik yaitu pemenuhan uji asumsi klasik. Uji asumsi klasik dari regresi linier berganda yang diterapkan pada penelitian ini meliputi uji normalitas, heterokesdastisitas, multikolinieritas dan autokorelasi.

Tabel 2 menunjukkan bahwa asumsi multikolinieritas tidak terpenuhi. Hal ini disebabkan variabel cakupan pemberian vitamin A, cakupan status imunisasi campak dan cakupan pelayanan kesehatan balita memiliki nilai VIF $>10$. Hal tersebut berarti terdapat korelasi yang tinggi antar ketiga variabel atau dikatakan terdapat multikolinieritas pada data tersebut.

Syarat dari analisis statistik regresi linier berganda yaitu data bebas dari multikolinieritas, sehingga dilakukan perbaikan atau penyelesaian. Asumsi multikolinieritas yang tidak terpenuhi diakibatkan oleh data yang mengalami redundant atau memasukkan variabel yang sama atau bahkan sama. Hal tersebut mengakibatkan terjadinya korelasi antar variabel bebasnya.

Pada penelitian ini penyelesaian masalah multikolinieritas menggunakan metode PCA. Metode PCA ini bertujuan untuk mereduksi atau menyederhanakan variabel yang sama dan membersihkan multikolinieritas (korelasi $=0$ ) dengan cara mereduksi (variabel baru/gabungan) tanpa menghilangkan variabel aslinya.

Hasil dari metode PCA, ketiga variabel yang mengalami multikolinieritas yaitu cakupan pemberian vitamin A, cakupan status imunisasi campak dan cakupan pelayanan kesehatan

Tabel 2. Hasil Uji Asumsi Klasik

\begin{tabular}{|c|c|c|c|}
\hline Asumsi & Metode & Hasil & Kesimpulan \\
\hline Normalitas & P plot & $\begin{array}{c}\text { Lengkung } \\
\text { kurve } \\
\text { nomal }\end{array}$ & $\begin{array}{l}\text { Asumsi } \\
\text { terpenuhi }\end{array}$ \\
\hline $\begin{array}{c}\text { Heterokes } \\
\text { dastisitas }\end{array}$ & Glejser & $\begin{array}{c}\text { Sig } 1,00 \\
>\alpha\end{array}$ & $\begin{array}{c}\text { Asumsi } \\
\text { terpenuhi }\end{array}$ \\
\hline $\begin{array}{l}\text { Multiko } \\
\text { linieritas }\end{array}$ & $\begin{array}{c}\mathrm{VIF} / \\
\text { Tolerance }\end{array}$ & $\begin{array}{c}\text { Terdapat } \\
3 \text { variabel } \\
\text { nilai VIF } \\
>10\end{array}$ & $\begin{array}{l}\text { Asumsi } \\
\text { tidak } \\
\text { terpenuhi }\end{array}$ \\
\hline $\begin{array}{c}\text { Auto } \\
\text { korelasi }\end{array}$ & $\begin{array}{l}\text { Dubin- } \\
\text { Watson }\end{array}$ & 1,733 & $\begin{array}{c}\text { Asumsi } \\
\text { terpenuhi }\end{array}$ \\
\hline
\end{tabular}

Tabel 3. Hasil Penyelesaian Multikolinieritas dengan Metode Principal Component Analysis (PCA) dengan meregresikan kembali variabel. Ketiga variabel tersebut direduksi menjadi satu variabel bebas baru (F1) yaitu cakupan pelayanan kesehatan pada balita

\begin{tabular}{lcc}
\hline \multicolumn{1}{c}{ Variabel } & Tolerance & VIF \\
\hline $\begin{array}{l}\text { Cakupan pemberian ASI } \\
\text { Eksklusif (X1) }\end{array}$ & 0,316 & 3,161 \\
\hline $\begin{array}{l}\text { Cakupan balita gizi buruk } \\
\text { (X2) }\end{array}$ & 0,781 & 1,280 \\
\hline $\begin{array}{l}\text { Cakupan pelayanan } \\
\text { kesehatan balita (F1) }\end{array}$ & 0,622 & 1,608 \\
\hline $\begin{array}{l}\text { Cakupan rumah tangga } \\
\text { ber-PHBS (X4) }\end{array}$ & 0,799 & 1,252 \\
$\begin{array}{l}\text { Cakupan Rumah Sehat } \\
\text { (X5) }\end{array}$ & 0,251 & 3,987 \\
\hline
\end{tabular}

pada balita direduksi menjadi satu variabel bebas baru (F1). Variabel (F1) direduksi untuk menghilangkan korelasi yang tinggi antar variabel bebas dan variabel ini dapat terwakili menjadi satu variabel saja (Sudrajat, 2016).

Terbentuknya variabel baru (F1) dari ketiga variabel tersebut menjadi bebas dari multikolinieritas sehingga asumsi terpenuhi untuk melanjutkan analisa selanjutnya.

Hasil dari uji pada metode PCA juga dapat digunakan untuk menentukan faktor yang dominan terhadap angka kejadian pneumonia balita di Jawa Timur dengan melihat nilai koefisien matrik. Berikut adalah hasil dari PCA dalam mengatasi masalah multikolinieritas terhadap variabel bebas penelitian ini. Tabel 3 menunjukkan bahwa nilai VIF dari seluruh variabel bebas pada penelitian ini bernilai $<10$. Hal ini berarti data penelitian sudah bebas dari masalah multikolinieritas, sehingga dapat di simpulkan bahwa asumsi multikolinieritas sudah terpenuhi. Seluruh asumsi terpenuhi variabel bebas pada penelitian ini menjadi lima variabel, yaitu variabel cakupan balita gizi buruk (X1), cakupan pemberian ASI eksklusif (X2), cakupan pelayanan kesehatan pada balita (F1), cakupan rumah tangga ber-PHBS (X4) dan cakupan rumah sehat $(\mathrm{X} 5)$. 
Tabel 4 menunjukkan bahwa variabel cakupan pelayanan kesehatan balita memiliki nilai tertinggi dibandingkan variabel lainnya. Hal ini berarti bahwa cakupan pelayanan kesehatan balita merupakan faktor risiko dominan yang memengaruhi angka kejadian pneumonia balita di Jawa Timur tahun 2014. Variabel cakupan pelayanan kesehatan pada balita meliputi cakupan pemberian vitamin A, status imunisasi campak dan pelayanan kesehatan balita minimal (delapan kali) $8 \mathrm{x}$.

Tabel 4. Faktor Risiko Penyebab Angka Kejadian Pneumonia Balita di Jawa Timur

\begin{tabular}{lc}
\hline \multicolumn{1}{c}{ Variabel } & $\begin{array}{c}\text { Koefisien } \\
\text { Matriks }\end{array}$ \\
\hline $\begin{array}{l}\text { Cakupan pemberian ASI } \\
\text { Eksklusif (X1) }\end{array}$ & 0,832 \\
\hline $\begin{array}{l}\text { Cakupan balita gizi buruk } \\
\text { (X2) }\end{array}$ & 0,604 \\
\hline $\begin{array}{l}\text { Cakupan pelayanan kesehatan } \\
\text { balita (F1) }\end{array}$ & 0,890 \\
\hline $\begin{array}{l}\text { Cakupan rumah tangga ber- } \\
\text { PHBS (X4) }\end{array}$ & 0,692 \\
Cakupan Rumah Sehat (X5) & 0,568 \\
\hline
\end{tabular}

Hasil metode PCA menunjukkan faktor dominan yang memengaruhi angka kejadian pneumonia balita di Jawa Timur tahun 2014. Hal ini diharapkan dapat menjadi masukkan bagi instansi pemegang kebijakan untuk lebih memperhatikan cakupan pelayanan kesehatan pada balita yang meliputi pemberian vitamin A, imunisasi campak untuk balita dan cakupan pelayanan kesehatan balita minimal (delapan kali) $8 x$.

\section{PEMBAHASAN}

Uji asumsi tidak adanya multikolinieritas pada suatu model regresi linier berganda merupakan syarat yang harus terpenuhi. Multikolineritas adalah terjadinya korelasi antar variabel bebas. Multikolinieritas terjadi apabila terdapat hubungan atau korelasi diantara beberapa variabel bebas. Hal ini di dukung dengan data penelitian mengenai angka kejadian pneumonia balita di Jawa Timur tahun 2014 yang terdiri dari 4 (empat) variabel bebas. Variabel bebas dari penelitian ini yaitu (1) cakupan pemberian ASI eksklusif, (2) cakupan pelayanan kesehatan balita (meliputi; cakupan pemberian vitamin A, cakupan status imunisasi campak dan cakupan pelayanan kesehatan balita minimal 8x), (3) cakupan rumah tangga ber-PHBS dan (4) cakupan rumah sehat.

Variabel penelitian ini serupa dengan penelitian tentang pemodelan kasus pneumonia balita dengan hasil yang menunjukkan faktor risiko, meliputi presentase balita masalah gizi buruk, presentase balita mendapatkan suplementasi vitamin A, jumlah pelayanan kesehatan pada balita, jumlah kepadatan penduduk, presentase rumah tangga ber-PHBS, presentase rumah sehat dan presentase rumah tangga miskin (Maghfiroh et al., 2015)

\section{Principal Component Analysis (PCA) dalam Mengatasi Multikolinieritas}

Adanya multikolinieritas dalam penelitian ini diketahui dengan melakukan analisis nilai VIF dan tolerance. Montgomery dan Peck (dalam Sudrajat 2016), mendefinisikan deteksi mulikolinieritas dengan metode VIF (Variance Inflation Factor) pada regresi linier berganda yang melibatkan $\geq$ dua variabel bebas. Nilai VIF yang menyatakan lebih besar dari 10 maka dapat dinyatakan bahwa teridentifikasi adanya korelasi antar variabel bebas atau adanya masalah multikolinieritas. Terdapat satu atau dua lebih nilai VIF yang besar menandakan adanya multikolinieritas pada variabel bebas penelitian.

Pernyataan pendeteksian multikolinieritas yang telah dipaparkan dibuktikan dan didukung dengan hasil penelitian yang menyatakan bahwa nilai VIF dari masing-masing variabel. Hasil analisis dari metode VIF menunjukkan bahwa ada tiga nilai yang $>10$ yaitu variabel cakupan pemberian vitamin A, cakupan status imunisasi campak dan cakupan pelayanan kesehatan balita. Variabel cakupan pemberian vitamin A memiliki nilai VIF sebesar 122,231, cakupan status imunisasi campak sebesar 129,638 dan cakupan pelayanan kesehatan balita sebesar 13,328 . Hal ini menyatakan bahwa benar adanya multikolinieritas pada ketiga variabel pada data penelitian ini. 
Metode PCA digunakan untuk mengatasi multikolinieritas pada penelitian ini. Hasil dari PCA yaitu mereduksi ketiga variabel bermultikolinieritas menjadi satu variabel yang bebas dari multikolinieritas. Variabel bebas baru (F1) tersebut memiliki nilai VIF $<10$ yakni sebesar 1,608 yang membuktikan bahwa metode PCA menyelesaikan masalah multikolinieritas tanpa menghilangkan variabel aslinya. Penelitian ini serupa dengan penelitian oleh Soemartini dengan hasil dari penelitian tersebut menunjukkan bahwa hasil dari penggunaan metode PCA akan mendapatkan variabel bebas yang bebas dari korelasi, bebas satu sama lainya, lebih sedikit jumlahnya daripada variabel asalnya, akan tetapi dapat menyerap mayoritas informasi yang terkandung dalam variabel asli atau dapat memberikan kontribusi pada varian seluruh variabel yang terwakili (Soemartini, 2008).

Pada penelitian ini juga membuktikan adanya kelemahan dari metode PCA. Metode PCA pada penelitian ini tidak dapat mengubah signifikansi pada variabel bebas terhadap variabel dependen. Beberapa variabel bebas yang menyatakan tidak signifikan ketika masih mengalami multikolinieritas, namun setelah diatasi dengan metode PCA beberapa variabel bebas tersebut tetap tidak signifikan. Secara teori bahwa variabel bebas seharusnya signifikan ketika sudah bebas dari masalah multikolinieritas. Hal ini membuktikan bahwa metode PCA masih memiliki kelemahan dalam analisisnya.

Hal tersebut serupa dengan penelitian yang mengevaluasi kelemahan dari metode PCR. Hasil dari penelitian tersebut menyatakan bahwa metode PCA/PCR memerlukan lebih banyak komponen untuk dapat menjelaskan keragaman yang lebih besar dan model regresi yang lebih baik (Sunaryo, 2011).

Faktor Risikoyang Dominan terhadap Angka Kejadian Pneumonia pada Balita di Jawa Timur

Cakupan pelayanan kesehatan balita merupakan faktor yang dominan atau paling berpengaruh terhadap angka kejadian pneumonia pada balita. Variabel cakupan pelayanan kesehatan balita meliputi cakupan pemberian vitamin A dan cakupan status imunisasi campak.
Hasil analisis data yang menyatakan bahwa cakupan pelayanan kesehatan balita merupakan faktor dominan dari angka kejadian pneumonia balita di dukung dengan penelitian lain yang terdahulu.

Hasil dari penelitian yang menunjukkan pentingnya pemberian vitamin A sebagai faktor dominan didukung oleh penelitian lain yang menjelaskan bahwa pemberian suplemen vitamin A yang harus diberikan setahun dua kali semenjak anak berusia enam bulan. Pemberian suplemen vitamin A berperan sebagai proteksi melawan infeksi, kekebalan tubuh dan mengatur pengembangan fungsi paru (Hartati, 2011).

Berdasarkan laporan data tingkat provinsi dari Profil Kesehatan Provinsi Jawa Timur tahun 2014 bahwa cakupan pemberian vitamin A mencapai 96,36\%. Pada tahun 2014 cakupan kunjungan bayi balita mencapai $95,43 \%$. Hal tersebut berarti bahwa cakupan kunjungan balita di pelayanan kesehatan signifikan dengan pemberian vitamin A pada balita. Semakin tinggi cakupan kunjungan balita semakin tinggi juga cakupan pemberian vitamin A dan semakin menurunkan angka kejadian pneumonia balita.

Cakupan imunisasi campak pada penelitian ini juga merupakan faktor dominan dari angka kejadian pneumonia balita. Cakupan imunisasi campak memberikan kepastian salah satu imunisasi yang wajib diberikan kepada balita. Hal ini menjadi pencegah utama keparahan dan kejadian komplikasi penyakit yang disebabkan menurunnya sistem kekebalan tubuh pada balita (Kemenkes RI, 2015).

\section{Hubungan Cakupan Pemberian Suplemen Vitamin A dengan Angka Kejadian Pneumonia Balita}

Pemberian suplemen vitamin A pada balita merupakan program upaya kesehatan bertujuan untuk menurunkan angka kesakitan dan kematian pada balita. Hal tersebut disebabkan karena vitamin A berfungsi untuk memperkuat sistem kekebalan tubuh. Berdasarkan program Kementerian Kesehatan Indonesia, terdapat dua bulan (Februari dan Agustus) dalam satu tahun dilaksanakannya pembagian suplementasi vitamin A. Subyek sasaran pemberian suplementasi vitamin A ini adalah anak balita berumur 6-59 bulan. 
Bayi dan balita memiliki faktor risiko terserangnya penyakit menular begitupun juga dengan penyakit pneumonia, diare maupun ISPA. Hal ini sering disebabkan karena daya tahan tubuh bayi dan balita masih rendah. Kandungan pada vitamin A merupakan zat gizi yang bermanfaat penting bagi balita karena dapat meningkatkan daya tahan tubuh atau antibodi. Bayi atau balita yang cukup akan pemenuhan suplementasi vitamin A, apabila terserang infeksi, maka penyakit tidak akan mudah menjadi parah dan membahayakan. Pemberian suplementasi vitamin A menurunkan angka kematian yaitu 30-54\%, maka untuk saat ini pentingnya pemberian vitamin A dikaitkan dengan kesehatan, kelangsungan hidup dan pertumbuhan balita (Kemenkes RI, 2015).

Tujuan diadakannya program pemberian suplementasi vitamin A adalah pencegahan terhadap terjadinya deviensi vitamin A terhadap bayi dan balita. Deviensi vitamin A pada balita dapat menyebabkan mudahnya bakteri ataupun virus yang masuk ke dalam host atau tubuh balita. Hal tersebut menyebabkan rentannya penyakit terhadap tubuh balita. Pneumonia salah satu penyakit yang hingga saat ini memberikan sumbangan meningkatnya angka kematian bayi dan balita.

\section{Hubungan Cakupan Status Imunisasi Campak terhadap Angka Kejadian Pneumonia Balita}

Kelangsungan hidup virus dapat berkembang baik di udara, benda maupun permukaan. Virus campak akan terletak di lendir hidung dan tenggorokan orang yang terinfeksi, sehingga penularannya dapat terjadi ketika orang tersebut batuk atau bersin. Penyakit komplikasi yang dapat terjadi karena virus campak yaitu meliputi infeksi telinga, diare, radang otak (ensephalitis) dan radang paru (bronchopneumonia). Penyebab utama terjadinya komplikasi adalah adanya penyebaran virus campak pada jaringan paru. Hal ini ditandai dengan adanya giant cell dan menyebabkan peradangan pada peribroncial paru. Terjadinya peradangan inilah yang disebut pneumonia. Berdasarkan hal tersebut dengan adanya pemberian imunisasi campak maka balita akan mendapatkan kekebalan aktif dan terhindar dari penyakit campak serta penyakit komplikasi dari campak pneumonia.
Hubungan cakupan imunisasi campak dengan kejadian pneumonia ini untuk mengurangi faktor yang meningkatkan kematian akibat ISPA, diupayakan imunisasi lengkap. Bayi dan balita yang memiliki status imunisasi lengkap bila menderita ISPA pada usia tersebut, perkembangan penyakitnya tidak akan menjadi lebih berat. Cara yang paling efektif adalah dengan pemberian imunisasi campak dan DPT (Kemenkes RI, 2015).

Menurut hasil penelitian Prabu menyatakan bahwa peningkatan jumlah imunisasi lengkap akan berperan besar dalam upaya penanggulangan ISPA. Bayi dan balita yang berstatus imunisasi lengkap apabila menderita ISPA, perkembangan penyakitnya tidak akan bertambah berat atau bahkan fatal. Imunisasi campak memberikan dampak yang efektif sekitar $11 \%$ dari kematian pneumonia pada balita. Imunisasi pertusis (DPT) sebesar 6\% dapat mencegah keparahan dan kematian pneumonia (Prabu, 2009). Hasil penelitian Lestari juga menunjukkan kejadian penyakit campak, pneumonia dan diare pada anak yang tidak mendapat imunisasi dasar lengkap lebih tinggi dibandingkan anak yang mendapatkan imunisasi dasar lengkap (Lestari et al., 2009). Hal tersebut menunjukkan bahwa imunisasi campak yang diberikan kepada balita memiliki banyak manfaat dalam pencegahan penyakit bukan hanya preventif untuk penyakit campak saja.

\section{Hubungan Cakupan Rumah Tangga Ber PHBS terhadap Angka Kejadian Pneumonia Balita}

Hasil analisis menunjukkan bahwa variabel cakupan rumah tangga yang mempraktikkan PHBS mempunyai hubungan yang signifikan terhadap angka kejadian pneumonia pada balita. Hasil statistik dengan $p$ value $0,032<\alpha(0,05)$ yang berarti bahwa variabel cakupan rumah tangga ber-PHBS memiliki hubungan positif atau signifikan terhadap angka kejadian pneumonia pada balita.

Menurut teori Blum dalam (Notoadmojo, 2007) faktor perilaku merupakan yang berperan penting dalam menentukan derajat kesehatan, sedangkan ketiga faktor lain meliputi faktor lingkungan, kualitas pelayanan kesehatan maupun genetika. Perubahan perilaku sangat 
penting untuk meningkatkan derajat kesehatan. Hal tersebut memang tidak mudah untuk dilakukan. Pelaksanaan PHBS sejak dini dalam keluarga dapat menciptakan keluarga yang sehat dan aktif di setiap upaya kesehatan masyarakat. Berdasarkan hal itu, penerapan PHBS dimulai dari unit masyarakat paling kecil dan utama yaitu rumah tangga.

Aktvitas PHBS adalah tindakan atau perilaku yang dilakukan atas dasar kesadaran sebagai hasil dari pembelajaran ilmu pengetahuan. Hal ini dapat mencegah terjadinya risiko penyakit dan sebagai perlindungan diri dari ancaman penyakit. Perilaku hidup bersih dan sehat memiliki tujuh indikator yang mampu menurunkan atau mengurangi risiko terjadinya pneumonia. Tujuh indikator tersebut meliputi, persalinan yang ditolong oleh tenaga kesehatan, bayi yang di beri ASI sejak lahir secara eksklusif, mempunyai kartu jaminan pemeliharaan kesehatan, ketersediaan air bersih, ketersediaan jamban, luas lantai, jumlah penghuni yang sesuai syarat dan lantai rumah bukan hanya berlapiskan tanah saja.

Berdasarkan hal tersebut faktor cakupan rumah tangga yang melakukan PHBS mampu mewakili hubungan dua variabel lainnya yaitu cakupan pemberian ASI eksklusif dan cakupan rumah sehat.

\section{SIMPULAN DAN SARAN}

\section{Simpulan}

Penyelesaian masalah multikolinieritas pada penelitian ini dengan menggunakan metode regresi komponen utama atau PCA. Metode PCA menghasilkan variabel bebas baru (F1) yang terbentuk dari dua (3) variabel bebas yang mengalami multikolinieritas pada analisis sebelumnya. Variabel baru (F1) ini menunjukkan tidak adanya multikolinieritas saat di uji kembali menggunakan metode VIF melalui regresi linier berganda. Nilai VIF variabel baru (F1) sebesar $1,608<10$, tidak adanya multikolinieritas pada variabel.

Hasil dari Metode PCA pada analisis ini juga menunjukkan kelemahan analisis. Metode PCA tidak mampu memberikan hasil analisis perubahan signifikansi hubungan antara variabel bebas dengan variabel dependennya setelah dilakukan pembersihan multikolinieritas dalam suatu model regresi.

Metode regresi komponen utama (PCR) juga menghasilkan faktor risiko yang dominan terhadap angka jumlah kejadian pneumonia pada balita di Jawa Timur tahun 2014. Cakupan pelayanan kesehatan balita (variabel bebas baru yang meliputi cakupan pemberian vitamin $\mathrm{A}$ dan cakupan imunisasi campak) merupakan faktor risiko yang dominan dimana pada hasil PCA menghasilkan nilai koefisien matrik sebesar 0,890 atau $89,0 \%$. Hal ini berarti bahwa sebesar $89 \%$ cakupan pelayanan kesehatan balita lebih berpengaruh terhadap angka kejadian pneumonia balita dibandingkan dengan faktor lainnya. Semakin rendahnya cakupan pelayanan kesehatan balita juga sebanding dengan semakin menurunnya cakupan pemberian vitamin A serta imunisasi campak. Sehingga hal tersebut dapat menyebabkan risiko pneumonia pada balita.

Data faktor risiko angka kejadian pneumonia pada balita telah memenuhi uji asumsi klasik regresi linier berganda selain multikolinieritas.

\section{Saran}

Penggunaan metode regresi komponen utama atau PCA dalam mengatasi masalah multikolinieritas memiliki kelebihan dan kelemahan. Mengatasi masalah multikolinieritas sebaiknya menggunakan metode regresi komponen utama/PCA, karena metode ini memiliki kelebihan dibanding metode lainnya yaitu dapat menghilangkan korelasi antar variabel bebasnya (korelasi $=0$ ) tanpa menghilangkan variabel asalnya. Penelitian dengan kondisi variabel bebas ketika menggunakan PCR menghasilkan terbentuknya variabel baru, sebaiknya melihat terlebih dahulu apakah variabel tersebut logis atau sesuai teori tidak jika digabungkan. Ketika variabel menyatakan tidak logis sesuai teori maka sebaiknya melanjutkan analisis menggunakan metode ROBPCA. Metode ROBPCA merupakan metode yang lebih baik digunakan di penelitian dengan kondisi seperti ini.

Bagi instansi tempat pengambilan data yaitu Dinas Kesehatan Provinsi Jawa Timur, dengan melihat hasil penelitian ini yang menemukan faktor risiko dominan. Faktor risiko dominan 
adalah cakupan pelayanan kesehatan balita. Hal ini diharapkan instansi mengambil langkah atau kebijakan program preventif dan promotif khususnya dalam penurunan angka kejadian pneumonia pada balita.

\section{DAFTAR PUSTAKA}

Dinas Kesehatan Provinsi Jawa Timur. 2015. Profil Kesehatan Jawa Timur 2014. Surabaya, Dinas Kesehatan Provinsi Jawa Timur. Tersedia di: www.depkes.go.id/resources/.../profil/ PROFIL...PROVINSI_2014/15_Jatim_2014. pdf. [diakses 12 Januari 2017].

Hartati, S. 2011. Analisis Faktor Risiko yang Berhubungan dengan Kejadian Pneumonia pada Anak Balita di RSUD Pasar Rebo Jakarta. Tesis. Universitas Indonesia. Tersedia di: <https://lib.ui.ac.id/ file?file=digital/20282632-T Susi Hartati.pdf. [17 Februari 2017].

Kementerian Kesehatan RI. 2015. Profil Kesehatan Indonesia Tahun 2014. Jakarta, Kementerian Kesehatan RI. Tersedia di: www.depkes. go.id/.../profil-kesehatan-indonesia/profilkesehatan-indonesia-2014.pdf. [diakses 12 januari 2017]

Lestari C.S.W, Emilianan Tjitra dan Sandjaja. 2009. Dampak Status Imunisasi pada Anak Balita di Indonesia terhadap Kejadian Penyakit. Media Penelitian dan Pengembangan Kesehatan. Badan Litbang Kesehatan hal. S5-S12.<https://litbangkesehatan/ file?file $=$ digital $/ 20282632$-T.pdf. [diakses 12 januari 2017]
Magfiroh, F., I Nyoman, L., dan Purhadi. 2015. Pemodelan Kasus Pneumonia Balita di Kota Surabaya dengan Geographically Weighted Poisson Regression dan Flexibly Shaped. Skripsi. Surabaya: FMIPA Institut Teknologi Sepuluh Nopember, Statistika.

Notoadmojo. 2007. Promosi Kesehatan (Blum, Planning for Health Development). Jakarta: Rineka Cipta. Tersedia pada: [e-journal]: http:// wp-content/uploads/2015/11/109-114ZARAZ-ONA.pdf. diakses 31 Juli 2017].

Prabu. 2009. Faktor Resiko ISPA pada balita. Tersedia pada: [e-journal]:http://putraprabu. wordpress.com/2009/01/15/faktorrisiko-ispapada-balita/ [diakses 24 Juni 2017]

Soemartini. 2008. Principal Component Analysis Sebagai Salah Satu Metode Mengatasi Masalah Multikolinieritas. Jatinangor: FMIPA Universitas Padjadjaran. [e-journal]. 6(5). pp.1-9. Tersedia di: https://elmurobbie.files. com/2009/06/principal-component-analysspca2.pdf.[diakses 20 Juni 2017].

Sudrajat, A. 2016. PCA dalam mengatasi Multikolinieriatas pada Faktor Mempengaruhi AHH penduduk Jawa Timur Tahun 2014. Surabaya: FKM, Universitas Airlangga. hal. 34-35.

Sunaryo, S. 2011. Mengatasi Masalah Multikolinieritas dan Outlier dengan Pendekatan ROBPCA (Studi Kasus Analisis Regresi Angka Kematian Bayi di Jawa Timur). Skripsi. Surabaya: FMIPA Institut Teknologi Sepuluh Nopember, Statistika. [e-journal]. 6(5). pp.1-9. Tersedia di: download.portalgaruda. org $/$ article.php? article $=143945 \& \mathrm{val}=980 /$ download/documents/ipi14395.pdf. [diakses 20 Juni 2017]. 